\title{
Toxicity assessment of effluents
}

\author{
T. Tišler ${ }^{1} \&$ J. Zagorc-Končan ${ }^{2}$ \\ ${ }^{I}$ National Institute of Chemistry, Ljubljana, Slovenia \\ ${ }^{2}$ Faculty of Chemistry and Chemical Technology, \\ University of Ljubljana, Slovenia
}

\begin{abstract}
Experiences have shown that the effective control of effluent discharges has contributed to continuous improvement of the receiving waters. An important intrinsic property of effluent is toxicity, which should be properly evaluated to protect the aquatic ecosystems. Previous experiences have shown that identification of individual potentially toxic substances has many limitations. Nowadays, an integrated strategy is used in programmes for monitoring the quality of effluent discharges, which involves chemical determinations as well as toxicity tests. In Slovenian regulations, acute toxicity assessment using water fleas is a standard part of the monitoring programme for effluents discharging into receiving streams if toxic compounds in the effluent are expected. The aim of this study was to assess the adequacy of the daphnid acute toxicity test for characterisation of effluents containing different hazardous chemicals. In most cases Daphnia magna was found to be very sensitive to toxic effluents in comparison to luminescent bacteria Vibrio fischeri, algae Desmodesmus subspicatus and fish Danio rerio. However, in some cases, other organisms were more sensitive than daphnids, for example algae $D$. subspicatus when exposed to effluent from the chemical industry. Our results show that using a battery of test species and endpoints results in more reliable and comprehensive quality assessment of effluents discharging into receiving streams.
\end{abstract}

Keywords: Danio rerio, Daphnia magna, Desmodesmus subspicatus effluent quality, monitoring programme, regulation, toxicity, Vibrio fischeri.

\section{Introduction}

Effluents, either from industrial or municipal sources, are very important sources of chemicals entering aquatic ecosystems. They may contain hundreds to 
thousands of chemicals with only a few being responsible for aquatic toxicity. The consequences of discharging toxic effluents into receiving water or biological wastewater treatment plants are always the same; the release of toxic and dangerous chemicals into the aquatic environment. Therefore, a reliable and effective assessment of effluent toxicity plays an important role in protecting the aquatic ecosystems. For many years, water quality policy was based on the "chemical-specific" approach, but past experiences have shown several limitations in assessment of effluent toxicity using this approach. The most relevant are the inability to account for the bioavailability of the pollutants and the possible effects between compounds in the effluent sample. Nowadays, the acute and chronic toxicity tests are an integrated part of monitoring programmes for effluent discharging into receiving streams in European countries [1]. They provide a direct measure of toxicity of all chemicals, although the list of chemical determinations is restricted. Due to a wide range of pollutants in the effluents with different modes of action, the effluent monitoring programme should involve a suite of aquatic organisms representing different trophic levels: i.e. decomposers (bacteria), producers (algae), and consumers (crustacea, fish). $[2,3]$.

In Slovenian regulations, the monitoring programme for effluents is mainly based on the traditional "chemical-specific" approach, which involves conventional chemical determinations and measurement of priority pollutants. Acute toxicity evaluation of effluents discharging into receiving streams is prescribed when toxic substances in the effluent are expected [4]. The permissions for effluents discharging into receiving streams set the limit values for chemical parameters and toxicity, which depend on the type of industry.

The aim of our study was to evaluate the adequacy of Daphnia magna as a test organism for the toxicity assessment of effluents from different industries. In addition to the obligatory acute toxicity test with daphnids, toxic impacts of effluents were also studied on bacteria Vibrio fischeri, green algae Desmodesmus subspicatus, and zebrafish Danio rerio. The effluent samples originating from the tannery, textile, chemical, pharmaceutical, and metal industries were also analysed for conventional chemical parameters and some specific expected pollutants.

\section{Material and methods}

Flow proportional samples of effluents were collected for 6 hours and then stored at $+4^{\circ} \mathrm{C}$ for analyses performed within 3 days or frozen at $-18^{\circ} \mathrm{C}$ until use. The collected samples were analysed according to the standard procedures [5].

The luminescence of marine liquid-dried bacteria Vibrio fischeri NRRL-B11177 was measured on a LUMIStox 300 luminometer at $15 \pm 0.2^{\circ} \mathrm{C}$ after $30 \mathrm{~min}$ of exposure according to ISO standard [6]. The $30 \mathrm{~min}$ EC20, EC50 with $95 \%$ confidence limits, and EC80 values were calculated using a log-linear regression analysis [7].

The green algae Desmodesmus subspicatus Chodat 1926 (CCAP 276/20) was obtained from the Culture Collection of Algae and Protozoa, Cumbria, United 
Kingdom. The stock culture of algae was maintained in a nutrient solution according to Jaworski [8] at a constant room temperature of $21 \pm 1^{\circ} \mathrm{C}$ and under continuous fluorescent illumination (4000 lux) on an orbital shaker. In the toxicity test, algal growth was determined by measuring the cell density [9]. Test flasks were constantly shaken and illuminated with intensity of 7000 lux. Algal density was determined by counting cells in a Bürker counting chamber at 0,24 , 48 , and $72 \mathrm{~h}$. The inhibition of algal growth was determined by a comparison of growth rates and the $72 \mathrm{~h} \mathrm{IC10,} \mathrm{IC50} \mathrm{and} \mathrm{IC90} \mathrm{values} \mathrm{were} \mathrm{derived} \mathrm{from} \mathrm{the}$ linear regression analysis.

Water fleas Daphnia magna Straus 1820 were obtained from the Institut für Wasser, Boden und Lufthygiene des Umweltbundesamtes, Berlin. They were cultured at $21+1^{\circ} \mathrm{C}$ in $3-\mathrm{L}$ aquariums containing $2.5 \mathrm{~L}$ of modified M4 medium [10] and illuminated with fluorescent lamps for $12 \mathrm{~h}$ per day with a light intensity of approximately 1800 lux. Daphnids were fed a diet of the green algae D. subspicatus corresponding to $0.13 \mathrm{mg} \mathrm{C} /$ daphnia per day. A toxicity test was conducted according to ISO standard [11]; the immobility of daphnids was determined after $24 \mathrm{~h}$ and $48 \mathrm{~h}$ of exposure. Probit analysis was used to calculate the EC10, EC50 with corresponding 95\% confidence limits, and EC90 [12].

Zebrafish Danio rerio Hamilton Buchanan were obtained from a commercial supplier. They were acclimated to the test temperature at least seven days prior the beginning of an experiment. During acclimatization the fish were fed with commercial fish food and the tanks were illuminated with fluorescent bulbs for $12 \mathrm{~h}$ per day. The acute toxicity test with zebrafish was conducted in a static exposure system in $3-\mathrm{L}$ aquariums containing $2.5 \mathrm{~L}$ of test samples at $21 \pm 1^{\circ} \mathrm{C}$ [13]. The endpoint observed was fish survival during the $96 \mathrm{~h}$ of exposure. The 96h LC10, LC50 with 95\% confidence limits, and LC90 values were calculated with the probit analysis [12].

\section{Results and discussion}

\subsection{Effluent characterisation}

Physico-chemical parameters of effluents are summarised in Table 1. Both samples from a textile, chemical, metal, pharmaceutical industry and tannery were highly polluted with organic substances; the concentrations of COD and BOD5 exceeded the permissible limit levels for discharging effluents into receiving streams. The sample from textile industry (1) as well as the samples from pharmaceutical, chemical (treated) and metal industry indicating poorly biodegradability as the BOD5/COD ratio was less than 0.3 . The raw sample from chemical industry contained high concentrations of specific pollutants such as methanol $(259 \mathrm{mg} / \mathrm{L})$, formaldehyde $(921 \mathrm{mg} / \mathrm{L})$ and butanol $(101 \mathrm{mg} / \mathrm{L})$, but significantly lower concentrations (methanol $=12 \mathrm{mg} / \mathrm{L}$; formaldehyde $=55$ $\mathrm{mg} / \mathrm{L}$; butanol $<10 \mathrm{mg} / \mathrm{L}$ ) were measured in the biologically treated sample. The effluent from tannery was polluted with ammonium, total phosphorus, sulphate, sulphide $(1.7 \mathrm{mg} / \mathrm{l})$, chromium $(1.8 \mathrm{mg} / \mathrm{L})$, and aluminium $(2.7 \mathrm{mg} / \mathrm{L})$. The sample from the metal industry contained copper $(3.8 \mathrm{mg} / \mathrm{L})$, chromium $(8.4$ 
$\mathrm{mg} / \mathrm{L})$, nickel $(2.41 \mathrm{mg} / \mathrm{L})$ and zinc $(0.15 \mathrm{mg} / \mathrm{L})$. The increased concentrations of total suspended solids, ammonium and phosphorus were measured in the sample from pharmaceutical industry (Table 1).

Table 1: $\quad$ Physico-chemical parameters of effluent samples.

\begin{tabular}{|c|c|c|c|c|c|c|c|}
\hline \multirow{3}{*}{$\begin{array}{l}\text { Industry } \\
\mathrm{pH} \\
\end{array}$} & \multirow{3}{*}{\begin{tabular}{|c|} 
Textile 1 \\
8.4 \\
\end{tabular}} & \multirow{3}{*}{\begin{tabular}{|r|} 
Textile2 \\
9.3 \\
\end{tabular}} & \multicolumn{2}{|c|}{ Chemical } & \multirow{3}{*}{$\begin{array}{c}\text { Tannery } \\
7.7 \\
\end{array}$} & \multirow{3}{*}{$\begin{array}{c}\text { Metal } \\
4.8 \\
\end{array}$} & \multirow{3}{*}{\begin{tabular}{|c|} 
Pharm \\
8.0 \\
\end{tabular}} \\
\hline & & & Raw & eated & & & \\
\hline & & & 4.8 & 7.9 & & & \\
\hline $\begin{array}{l}\text { COD } \\
(\mathrm{mg} / \mathrm{L})\end{array}$ & 836 & 275 & 2114 & 246 & 2920 & 124 & 1326 \\
\hline $\begin{array}{l}\mathrm{BOD}_{5} \\
(\mathrm{mg} / \mathrm{L})\end{array}$ & 20 & 210 & 1348 & 55 & 2085 & 34.4 & 10 \\
\hline $\begin{array}{l}\mathrm{TSS} \\
(\mathrm{mg} / \mathrm{L})\end{array}$ & 1 & 1 & 429 & 371 & 463 & 1 & 114 \\
\hline $\begin{array}{l}\text { N-Kjehl } \\
\text { (mg/L) }\end{array}$ & / & 15.7 & 237.3 & 233 & / & 9.0 & 111 \\
\hline $\begin{array}{l}\mathrm{NH}_{4}^{+}-\mathrm{N} \\
(\mathrm{mg} / \mathrm{L})\end{array}$ & 29.2 & 3.1 & 30.5 & 59 & 184.0 & 9.0 & 77.0 \\
\hline $\begin{array}{l}\mathrm{NO}_{3}^{-} \\
(\mathrm{mg} / \mathrm{L})\end{array}$ & $<0.5$ & 4.4 & 1 & 1 & 1 & 40.6 & $<0.5$ \\
\hline $\begin{array}{l}\mathrm{NO}_{2}^{-} \\
(\mathrm{mg} / \mathrm{L})\end{array}$ & $<0.5$ & $<0.2$ & / & 1 & 1 & $<0.2$ & $<0.5$ \\
\hline $\begin{array}{l}\text { P total } \\
(\mathrm{mg} / \mathrm{L})\end{array}$ & 3.5 & I & $<0.2$ & 0.6 & 6.4 & 1 & 4.3 \\
\hline $\begin{array}{l}\mathrm{SO}_{4}{ }^{2-} \\
(\mathrm{mg} / \mathrm{L})\end{array}$ & 523 & 20.5 & / & 1 & 1256 & 96.5 & l \\
\hline $\begin{array}{l}\mathrm{Cl}^{-} \\
(\mathrm{mg} / \mathrm{L})\end{array}$ & 30.7 & 9.9 & / & / & 1 & 62.1 & 30.7 \\
\hline
\end{tabular}

\subsection{Toxicity to bacteria, algae, daphnids and fish}

The final toxicity results are given in tables 2 and 3 .

All tested organisms were affected by toxic compounds in the first sample from a textile industry; the highest response was observed in the case of daphnids. The second sample from the textile industry was slightly toxic to daphnids. The $34 \%$ of luminescence inhibition was measured in the sample with $80 \mathrm{v} / \mathrm{v} \%$ of this effluent and $40 \%$ mortality of zebrafish was found in the undiluted sample. The sample was non-toxic to algae. Raw, untreated sample from chemical industry was highly toxic to all tested organisms; the most sensitive species was found to be $D$. subspicatus. However, toxicity significantly decreased in the biologically treated sample, but slight toxicity still remained in the case of daphnids and zebrafish (Table 2).

The sample from tannery was very toxic to bacteria and zebrafish followed by daphnids and algae. The highest toxicity among effluents was detected in the sample from metal industry; the lowest EC50 value was obtained for daphnids 
$(48 \mathrm{~h}$ EC50 $=0.095 \mathrm{v} / \mathrm{v} \%)$ followed by zebrafish $(96 \mathrm{~h}$ LC50 $=0.84 \mathrm{v} / \mathrm{v} \%)$ and algae $(72 \mathrm{~h}$ IC50 $=1.4 \mathrm{v} / \mathrm{v} \%)$. However, the effluent sample was non-toxic to luminescence of Vibrio fischeri. Toxic compounds in the sample from pharmaceutical industry induced similar sensitivity of bacteria, daphnids and algae.

Table 2: Toxicity of effluent samples from the textile and chemical industries to bacteria, daphnids, zebrafish and algae.

\begin{tabular}{|c|c|c|c|c|}
\hline $\begin{array}{l}\text { Effluent from } \\
\text { industry }\end{array}$ & Textile 1 & Textile 2 & $\begin{array}{c}\text { Chemical } \\
\text { Raw }\end{array}$ & $\begin{array}{c}\text { Chemical } \\
\text { Treated }\end{array}$ \\
\hline \multicolumn{5}{|l|}{ V.fischeri 30min } \\
\hline IC20 (v/v \%) & 0.33 & ND & 0.5 & 0.38 \\
\hline $\begin{array}{l}\text { IC50 (v/v \%) } \\
(95 \% \text { CL) }\end{array}$ & $\begin{array}{c}2.5 \\
(2.4-2.6) \\
\end{array}$ & ND & $\begin{array}{c}1.6 \\
(1.5-1.7) \\
\end{array}$ & ND \\
\hline IC80 (v/v \%) & 20.6 & $\mathrm{ND}$ & 4.8 & $\mathrm{ND}$ \\
\hline \multicolumn{5}{|l|}{ D.magna $24 h$} \\
\hline EC10 (v/v \%) & 0.14 & 76.7 & 2.3 & 32.4 \\
\hline $\begin{array}{l}\text { EC50 (v/v \%) } \\
(95 \% \text { CL) }\end{array}$ & $\begin{array}{c}0.65 \\
(0.43-0.98)\end{array}$ & 99.3 & $\begin{array}{c}2.7 \\
(2.6-2.8)\end{array}$ & $\begin{array}{c}69.5 \\
(57.7-88.8)\end{array}$ \\
\hline EC90 (v/v \%) & 3.0 & $\mathrm{ND}$ & 3.2 & ND \\
\hline \multicolumn{5}{|l|}{ D.magna $48 \mathrm{~h}$} \\
\hline $\mathrm{EC10}(\mathrm{v} / \mathrm{v} \%)$ & 0.059 & 37.2 & 2.2 & 16.5 \\
\hline $\begin{array}{l}\text { EC50 (v/v \%) } \\
(95 \% \text { CL) }\end{array}$ & $\begin{array}{c}0.30 \\
(0.20-0.44)\end{array}$ & $\begin{array}{c}47.7 \\
(43.8-51.4)\end{array}$ & $\begin{array}{c}2.5 \\
(2.4-2.6) \\
\end{array}$ & $\begin{array}{c}35.3 \\
(28.6-42.8)\end{array}$ \\
\hline EC90 (v/v \%) & 1.6 & 61.3 & 2.9 & 75.7 \\
\hline \multicolumn{5}{|l|}{ D.rerio 96h } \\
\hline LC10 (v/v \%) & 10.6 & ND & 12.0 & 54.0 \\
\hline $\begin{array}{l}\mathrm{LC50}(\mathrm{v} / \mathrm{v} \%) \\
(95 \% \mathrm{CL})\end{array}$ & $\begin{array}{c}12.2 \\
(11.4-13.4)\end{array}$ & ND & $\begin{array}{c}15.5 \\
(13.7-18.6)\end{array}$ & $\begin{array}{c}69.6 \\
(64.3-77.1)\end{array}$ \\
\hline LC90 (v/v \%) & 14.2 & $\mathrm{ND}$ & 20.1 & 89.7 \\
\hline \multicolumn{5}{|l|}{$\begin{array}{l}\text { D.subspicatus } \\
72 \mathrm{~h}\end{array}$} \\
\hline IC10 (v/v \%) & 39.8 & ND & 0.43 & 9.5 \\
\hline IC50 (v/v \%) & 58.9 & ND & 0.79 & 1 \\
\hline IC90 (v/v \%) & 87.1 & ND & 1.45 & 1 \\
\hline
\end{tabular}

ND - not detected due to low toxicity.

The obtained results also revealed that the toxicity of samples to D. magna increased after the prolonged exposure period and therefore the exposure time of $48 \mathrm{~h}$ would be better indicator of toxicity.

The comparison of sensitivity of tested organisms is based on the comparison between the 30 min IC50 for bacteria, the 48h EC50 for daphnids, the $96 \mathrm{~h} \mathrm{LC50}$ for zebrafish and the $72 \mathrm{~h}$ IC50 for algae; the sensitivity range is given in Table 3 .

Mostly Daphnia magna revealed high sensitivity to different toxic compounds in tested samples. $V$. fischeri and D. subspicatus were the most 
sensitive species testing the effluent samples from the tannery and the raw sample from a chemical industry. Zebrafish responded to toxic compounds in the samples from tannery and metal industry (Table 4).

Table 3: Toxicity of effluent samples from the tannery, metal and pharmaceutical industries to bacteria, daphnids, zebrafish and algae.

\begin{tabular}{|c|c|c|c|}
\hline $\begin{array}{l}\text { Effluent from } \\
\text { industry }\end{array}$ & Tannery & Metal & Pharmaceutical \\
\hline \multicolumn{4}{|l|}{ V. fischeri 30min } \\
\hline IC20 (v/v \%) & 0.78 & ND & 0.24 \\
\hline $\begin{array}{l}\mathrm{IC} 50(\mathrm{v} / \mathrm{v} \%) \\
(95 \% \mathrm{CL})\end{array}$ & $\begin{array}{c}3.9 \\
(3.7-4.0) \\
\end{array}$ & ND & $\begin{array}{c}1.6 \\
(1.4-1.7) \\
\end{array}$ \\
\hline IC80 (v/v \%) & 21.7 & ND & 12.5 \\
\hline \multicolumn{4}{|l|}{ D. magna $24 h$} \\
\hline EC10 (v/v \%) & 25.8 & 0.080 & 0.28 \\
\hline $\begin{array}{l}\text { EC50 (v/v \%) } \\
(95 \% \text { CL) }\end{array}$ & $\begin{array}{c}31.6 \\
(29.8-33.4)\end{array}$ & $\begin{array}{c}0.19 \\
(0.15-0.36) \\
\end{array}$ & $\begin{array}{c}1.8 \\
(0.57-2.7)\end{array}$ \\
\hline EC90 (v/v \%) & 38.7 & 0.45 & 10.8 \\
\hline \multicolumn{4}{|l|}{ D. magna $48 h$} \\
\hline $\mathrm{EC10}(\mathrm{v} / \mathrm{v} \%)$ & 20.1 & 0.037 & 0.51 \\
\hline $\begin{array}{l}\text { EC50 (v/v \%) } \\
(95 \% \text { CL) }\end{array}$ & $\begin{array}{c}25.6 \\
(21.7-27.5)\end{array}$ & $\begin{array}{c}0.095 \\
(0.071-0.17) \\
\end{array}$ & $\begin{array}{c}1.4 \\
(0.86-1.8)\end{array}$ \\
\hline EC90 (v/v \%) & 32.6 & 0.25 & 3.7 \\
\hline \multicolumn{4}{|l|}{ D. rerio $96 \mathrm{~h}$} \\
\hline LC10 (v/v \%) & 3.9 & 0.56 & 21.7 \\
\hline $\begin{array}{l}\mathrm{LC50}(\mathrm{v} / \mathrm{v} \%) \\
(95 \% \mathrm{CL})\end{array}$ & $\begin{array}{c}7.3 \\
(5.3-9.2) \\
\end{array}$ & $\begin{array}{c}0.84 \\
(0.69-0.97) \\
\end{array}$ & $\begin{array}{c}23.3 \\
(22.4-24.2) \\
\end{array}$ \\
\hline LC90 (v/v \%) & 13.5 & 1.3 & 25.1 \\
\hline \multicolumn{4}{|l|}{$\begin{array}{l}\text { D. subspicatus } \\
72 \mathrm{~h}\end{array}$} \\
\hline $\mathrm{IC} 10(\mathrm{v} / \mathrm{v} \%)$ & 6.2 & 0.34 & 1.4 \\
\hline IC50 (v/v \%) & 48.6 & 1.4 & 3.0 \\
\hline IC90 (v/v \%) & ND & 6.0 & 6.5 \\
\hline
\end{tabular}

ND - not detected due to low toxicity.

The toxicity of industrial and urban wastewater samples have previously been tested by other authors and it was found that Nitellopsis obtusa and Thamnocephalus platyurus were very sensitive followed by Vibrio fischeri [14]. Comparing the acute and chronic toxicity of 30 different effluents to two crustacean species Daphnia magna and Thamnocephalus platyurus, bacteria Vibrio fischeri and algae Pseudokirchneriella subcapitata the bacteria $V$. fischeri revealed the highest sensitivity followed by $P$. subcapitata [15]. Authors also reported that Daphnia magna did not show high susceptibility to toxic effluents 
contrary to our results. However, a study [16] reported that daphnids were generally the most sensitive species and surprisingly, Vibrio fischeri did not show sensibility to toxic complex mixtures of toxic chemicals using a test battery with luminescence bacteria, Rhapidocellis subcapitata, Daphnia magna and Danio rerio. Relative sensitivity of bacteria, algae, daphnid, fish and plants was investigated testing the textile wastewater and found that the Vibrio fischeri and Desmodesmus subspicatus demonstrated higher sensitivity in comparison to other organisms [17]. Toxicity of effluents from pharmaceutical companies was studied using conventional biotests and Toxkits; they found that the algae Selenastrum capricornutum and Daphnia magna were sensitive to toxic effluents depending on the effluent sources and changes in production [18].

Table 4: Sensitivity ranking for test organisms exposed to wastewater samples from different sources.

\begin{tabular}{|l|l|}
\hline Effluent sample & $\begin{array}{l}\text { Descending order (sensitivity from left to } \\
\text { right) }\end{array}$ \\
\hline Textile industry 1 & $\begin{array}{l}\text { D. magna }>\text { V. fischeri }>\text { D. rerio }>D . \\
\text { subspicatus }\end{array}$ \\
\hline Textile industry 2 & $\begin{array}{l}\text { D. magna }>V . \text { fischeri }=\text { D. rerio }=D . \\
\text { subspicatus }\end{array}$ \\
\hline $\begin{array}{l}\text { Chemical industry } \\
\text { Raw sample }\end{array}$ & $\begin{array}{l}\text { D. subspicatus }>\text { V. fischeri }>\text { D. magna }> \\
\text { D. rerio }\end{array}$ \\
\hline Chemical industry \\
Treated sample & $\begin{array}{l}\text { D. magna }>\text { D. rerio }>\text { V. fischeri }=D . \\
\text { subspicatus }\end{array}$ \\
\hline Tannery & $\begin{array}{l}\text { V. fischeri }>\text { D. rerio }>\text { D. magna }>D . \\
\text { subspicatus }\end{array}$ \\
\hline Metal industry & $\begin{array}{l}\text { D. magna }>\text { D. rerio }>\text { D. subspicatus }>V . \\
\text { fischeri }\end{array}$ \\
\hline Pharmaceutical industry & $\begin{array}{l}\text { D. magna }=\text { V. fischeri }>\text { D. subspicatus }> \\
\text { D. rerio }\end{array}$ \\
\hline
\end{tabular}

\section{Conclusions}

The obtained results clearly demonstrate that no test species is sensitive to a wide range of toxic effluents. Daphnia magna immobilisation test is useful for taxation purposes due to high sensitivity level and simplicity of the toxicity test performance. However, the use of daphnids is inadequate for regular purposes concerning the discharges of effluents into receiving waters and we recommend including bacteria, algae and fish in the monitoring programme. Vibrio fischeri luminescence test is recommended as a screening test for effluents because it is fast and sensitive. A battery of tests involving the organisms from different taxonomic groups with different endpoints is recommended for more comprehensive and reliable characterisation of effluents flowing into receiving streams. Therefore, further studies are focused on the toxicity test based on a development of zebrafish fertilised eggs and the study of the applicability of biochemical biomarkers as a supplement to the conventional toxicity tests. 


\section{References}

[1] Power, E.A., Boumphrey, R.S. International trends in bioassay use for effluent management. Ecotoxicology, 13, pp. 377-398, 2004.

[2] Dorn, P.B., van Compernolle, R. Effluents. In: Rand GM. editor. Fundamentals of Aquatic Toxicology: Effects, Environmental Fate and Risk Assessment. Taylor and Francis, Washington, USA, p.903-937, 1995.

[3] Johnson, I., Hutchings, M., benstead, R., Thain, J., Whitehouse, P. Bioassay selection, experimental design and quality control/assurnce for use in effluent assessment and control.. Ecotoxicology, 13, pp. 437-447, 2004.

[4] Official Gazette of the Republic of Slovenia. Ordinance of emission of substances and heat for wastewater discharging from pollution sources. 35, p.2953-2960, 1996.

[5] APHA, AWWA, WEF. Standard Methods for the Examination of Water and Wastewater. Clesceri LS, Greenberg AE, Eaton AD. editors. $21^{\text {st }}$ Ed., Washington D.C., USA, 2005.

[6] International Organization for Standardization. Water quality Determination of the inhibitory effect of water samples on the light emission of Vibrio fischeri (Luminescent bacteria test) - Part 2: Method using liquid-dried bacteria. ISO 11348-2. Geneva, Switzerland, 1998.

[7] Dr. Bruno Lange. Dr. Lange LUMISsoft 4 software, Version 1.001, Düsseldorf, Germany, 2000.

[8] Thompson, A.S., Rhodes, J.C., Pettman, I. Culture collection of algae and protozoa, catalogue of strains. Culture Collection of Algae and Protozoa Freshwater Biological Association, Cumbria, UK, 1988.

[9] International Organization for Standardization. Water quality - Freshwater algal growth inhibition test with unicelullar green algae. ISO 8692. Geneva, Switzerland. 2004.

[10] Kühn, R., Pattard, M., Pernack, K.D., Winter, A. Results of the harmful effects of water pollutants to Daphnia magna in the $21 \mathrm{~d}$ reproduction test. Wat Res, 23, p.501-510, 1984.

[11] International Organization for Standardization. Water quality Determination of the inhibition of the mobility of Daphnia magna Straus (Cladocera, Crustacea). ISO 6341. Geneva, Switzerland, 1996.

[12] US Environmental Protection Agency. US Environmental Protection Agency toxicity data analysis software. Environmental Monitoring Systems Laboratory, Cincinnati, Ohio, USA, 1994.

[13] International Organization for Standardization. Water quality Determination of the acute lethal toxicity of substances to a freshwater fish (Brachydanio rerio Hamilton Buchanan, Teleostei, Cyprinidae), Part 1: Static method. ISO 7346-1. Geneva, Switzerland, 1996.

[14] Manusadžianas, L., Balkelyte, L., Sadauskas, K., Blinova, I., Pollumaa, L., Kahru, A. Ecotoxicological study of Lithuanian and Estonian wastewaters: selection of the biotests and correspondence between toxicity and chemicalbased indices. Aquatic Toxicology, 63, p. 27-41, 2003. 
[15] Vindimian, E., Garric, J., Flammarion, P., Thybaud, E., Babut, M. An index of effluent aquatic toxicity designed by partial least squares regression using acute and chronic tests and expert judgements. Environ Toxicol Chem., 18, pp. 2386-2391, 1999.

[16] Pederson, F., Petersen, G.I. Variability of species sensitivity to complex mixtures. Wat Sci Tech, 33, pp. 109-119, 1996.

[17] Rosa, E.V.C., Simionato, E.L., de Souza Sierra, M.M., Beroli, S.L., Radetski, C.M. Toxicity-based criteria for the evaluation of textile wastewater treatment efficiency. Environ Toxicol Chem., 20, pp. 839-845, 2001.

[18] Van der Wielen, C., Persoone, G., Goyvaerts, M.P., Neven, B., Quaghebeur, D. Toxicity of effluents o three pharmaceutical companies as assessed with a battery of tests. Tribune de L'Eau, 564/4, pp. 19-29, 1993. 